\title{
Characterization of Copper(II) Interactions with Sinefungin, a Nucleoside Antibiotic: Combined Potentiometric, Spectroscopic and DFT Studies
}

\author{
Maria Jaworska, ${ }^{1}$ Piotr Lodowski, ${ }^{1}$ Ariel Mucha, ${ }^{2}$ Wojciech Szczepanik, ${ }^{2}$ Gianni Valensin, ${ }^{3}$ \\ Massimo Cappannelli, ${ }^{3}$ and Małgorzata Jeżowska-Bojczuk ${ }^{2}$ \\ ${ }^{1}$ Department of Theoretical Chemistry, Faculty of Mathematics, Physics and Chemistry, University of Silesia, \\ 14 Bankowa St., 40-007 Katowice, Poland \\ ${ }^{2}$ Department of Bioinorganic and Biomedicinal Chemistry, Faculty of Chemistry, University of Wrocław, \\ F. Joliot-Curie 14, 50-383 Wrocław, Poland \\ ${ }^{3}$ Department of Chemistry, Faculty of Mathematical, Physical, and Natural Sciences, University of Siena, \\ Via Aldo Moro, I-53100 Siena, Italy
}

Received 11 October 2007; Accepted 9 November 2007

Recommended by Imre Sóvágó

\begin{abstract}
Interactions between sinefungin and copper(II) ions were investigated. Stoichiometry and stability constants of the metal-free system and two mononuclear complexes present in solution were determined on the basis of potentiometric data analysis. The results were compared to the $\mathrm{Cu}$ (II)-ornithine system due to structural similarities between both molecules. Combined spectroscopic and theoretical studies allowed for determination of coordination pattern for the $\mathrm{Cu}(\mathrm{II})$-sinefungin complexes. At acidic $\mathrm{pH}$, copper is bound in "glycine-like" coordination mode, identical with that of ornithine. This involves $\alpha$-amino group and the carboxyl oxygen. At higher $\mathrm{pH}$, a "bis-complex" is formed by two sinefungin molecules. The second ligand binds in equatorial position displacing two water molecules, what results in the stable $\{2 \mathrm{~N}, 2 \mathrm{O}\}$ coordination. Both axial positions are supposed to be occupied by $\mathrm{N} 1$ nitrogen donors of adenine moiety, what is confirmed by DFT calculations. They interact indirectly with copper(II) through water molecules as the result of dominant syn conformation of purine.
\end{abstract}

Copyright (C) 2007 Maria Jaworska et al. This is an open access article distributed under the Creative Commons Attribution License, which permits unrestricted use, distribution, and reproduction in any medium, provided the original work is properly cited.

\section{INTRODUCTION}

Nucleobases and nucleosides, the structural particles ofnucleotides, play relevant roles in several metabolic processes. It is, therefore, not surprising that their analogs are investigated as potential therapeutic agents [1-3]. Sinefungin (SFG, Figure 1), an antifungal and antiparasitic nucleoside antibiotic, is a natural product of Streptomyces griseolus and S. incarnatus $[4,5]$. SFG is active against a number of protozoan [6], inhibits tumor cell invasion in vitro [7], as well as virus multiplication [8], and cell transformation [9]. Structurally, SFG represents a wide range of compounds that combine aminoacids with nucleobases [10-14].

SFG comprises ornithine and adenosine nucleoside residues. Ornithine is well known to act as a precursor in one of the two possible routes to the biosynthesis of putrescine [15], the source of the diaminobutane residue for spermidine and spermine $[16,17]$. Both these biogenic amines take part in many biological processes [18-20] in almost all living and even cancer cells [21]. The search for ornithine analogues that inhibit polyamine biosynthesis $[22,23]$ or act as new anticancer drugs [24] as well as the continuous research on biological activity of various derivatives of nucleosides confirm the importance of the moieties combination in SFG.

Transition metal ions play fundamental roles in biological processes. It has been widely accepted that copper is an essential trace element which forms an integral component of many important enzymes and is required for growth and development in a wide range of species, from bacteria to man [25-27]. However, coordination of metal ions to bioactive ligands may also affect their toxicity. In fact, some metal complexes (e.g., $\mathrm{Fe}(\mathrm{II})$ and $\mathrm{Cu}(\mathrm{II})$ ) of organic compounds used as drugs [28-30] were found to be less toxic than the "native" forms, while maintaining the medical activity. On the 


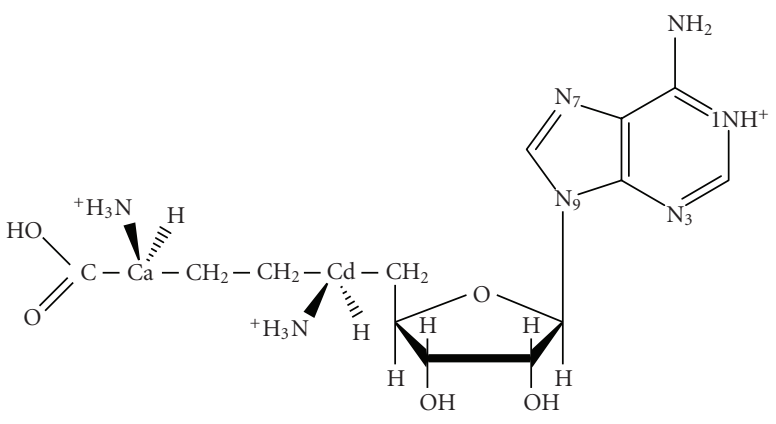

(a)

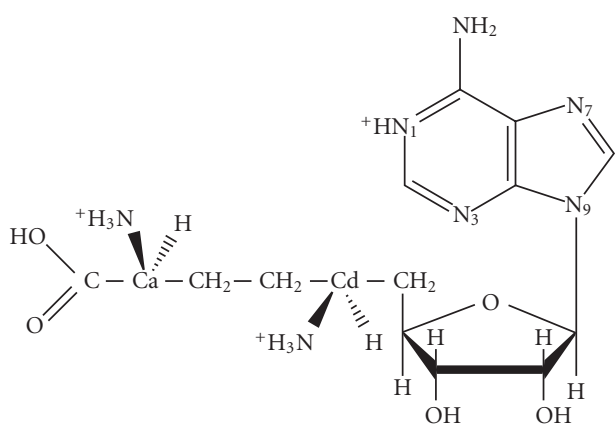

(b)

FIGURE 1: The fully protonated molecule of sinefungin in its two conformers, (a) anti and (b) syn.

TABLE 1: The protonation constants of sinefungin (L) and the stability constants of its $\mathrm{Cu}(\mathrm{II})$ complexes with the process sites indicated. The analogous values for ornithine are included for comparison.

\begin{tabular}{|c|c|c|c|}
\hline Species & $\log \beta$ & $\mathrm{pK}_{\mathrm{a}}$ & Deprotonation site \\
\hline $\mathrm{H}_{4} \mathrm{~L}^{3+}$ & $24.90(1)$ & 3.15 & $-\mathrm{COOH}$ \\
\hline $\mathrm{H}_{3} \mathrm{~L}^{2+}$ & 21.75(1) & 3.83 & $-\mathrm{N}_{1}\left(\mathrm{H}^{+}\right)$ \\
\hline $\mathrm{H}_{2} \mathrm{~L}^{+}$ & $17.918(9)$ & 8.355 & $-\mathrm{N}_{\alpha} \mathrm{H}_{3}^{+}$ \\
\hline $\mathrm{HL}^{ \pm}$ & $9.563(8)$ & 9.563 & $-\mathrm{N}_{\delta} \mathrm{H}_{3}{ }^{+}$ \\
\hline \multirow{2}{*}{$\mathrm{H}_{3}(\mathrm{Orn})^{2+}$} & $21.21^{\mathrm{a}}$ & 1.98 & \multirow{2}{*}{$-\mathrm{COOH}$} \\
\hline & $21.02^{\mathrm{b}}$ & 1.75 & \\
\hline \multirow{2}{*}{$\mathrm{H}_{2}(\mathrm{Orn})^{+}$} & $19.23^{\mathrm{a}}$ & 8.74 & \multirow{2}{*}{$-\mathrm{N}_{\alpha} \mathrm{H}_{3}{ }^{+}$} \\
\hline & $19.27^{\mathrm{b}}$ & 8.75 & \\
\hline \multirow{2}{*}{$\mathrm{H}(\text { Orn })^{ \pm}$} & $10.49^{\mathrm{a}}$ & 10.49 & \multirow{2}{*}{$-\mathrm{N}_{\delta} \mathrm{H}_{3}{ }^{+}$} \\
\hline & $10.52^{\mathrm{b}}$ & 10.52 & \\
\hline $\mathrm{CuHL}^{2+}$ & $15.83(2)$ & - & - \\
\hline $\mathrm{CuH}_{2} \mathrm{~L}_{2}{ }^{2+}$ & $31.12(2)$ & - & - \\
\hline \multirow{2}{*}{$\mathrm{CuH}(\mathrm{Orn})^{2+}$} & $17.8^{\mathrm{a}}$ & - & - \\
\hline & $17.812^{\mathrm{b}}$ & - & - \\
\hline \multirow{2}{*}{$\mathrm{CuH}_{2}(\mathrm{Orn})_{2}{ }^{2+}$} & $34.48^{\mathrm{a}}$ & 8.98 & - \\
\hline & $34.448^{\mathrm{b}}$ & - & - \\
\hline $\mathrm{CuH}(\mathrm{Orn})_{2}{ }^{+}$ & $25.50^{\mathrm{a}}$ & 9.97 & - \\
\hline $\mathrm{Cu}(\mathrm{Orn})_{2}$ & $15.53^{\mathrm{a}}$ & - & - \\
\hline
\end{tabular}

other hand, metal complexes (particularly $\mathrm{Cu}(\mathrm{II})$ ) of pharmacological agents, when compared with the free ligands, are widely reported to generate enhanced toxic effects $[31,32]$.

Significant amounts of free copper ions are unlikely to occur in vivo [33-35], what was alsoratified by the "fingerprint" of LDL oxidation products in extracts from atherosclerotic lesions, which is not consistent with the model of induction by free metals in vitro [36]. However, advanced lesions contain products consistent with free metal ion-catalyzed oxidation [36, 37]. Furthermore, some reports indicate that the concentration of a mobile fraction of copper ions in blood serum may increase as a result of a pathological state (e.g., harmful oxidative stress [38]), cancer, and inflammation [26]. Extracellular copper remains bound to a variety of low-molecular-weight ligands $[39,40]$, and its control is not as tight as that of the intracellular one, regulated by a series of chaperone proteins [35]. Cupric ions were also found in nuclei in association with chromosomal DNA [41]. It is then possible that some extracellular copper is transferred to SFG, what prompted us to perform the present study, which continues our research concerning the effect of $\mathrm{Cu}$ (II) on in vitro toxicity of drugs [32, 33].

Our previous papers reported the results of NMR investigations [42] as well as the oxidative activity of copper complexes with SFG in the presence of biologically important substances [43], and now we provide the detailed information about the coordination mode of copper-sinefungin complexes and their structures.

\section{RESULTS AND DISCUSSION}

Adenine and the other purine nucleobases, as well as their nucleosides and nucleotides, are known to undergo selfaggregation through stacking of aromatic moieties [4446]. However, at the concentrations used in this work (i.e., $0.7 \mathrm{mM}$ ), no self-association of the adenine ring of SFG is expected. This also holds for measurements concerning the metal ion complexes. As a consequence, the reported results all refer to the monomeric species.

\subsection{Acid-base properties of sinefungin}

SFG contains several potential donatives sites for metal ions and/or protons. Precise potentiometric titrations led to characterizing the acid-base properties of SFG, which behaves as a tetraprotic species. Table 1 shows the calculated values of the protonation constants that fit the range of $\mathrm{pH} 3-10$ and considerably differ from those of ornithine (also reported in Table 1).

The following deprotonation equilibria need then to be considered (L stands for SFG):

$$
\begin{aligned}
\mathrm{H}_{4} \mathrm{~L}^{3+} & \rightleftharpoons \mathrm{H}_{3} \mathrm{~L}^{2+}+\mathrm{H}^{+}, \\
\mathrm{H}_{3} \mathrm{~L}^{2+} & \rightleftharpoons \mathrm{H}_{2} \mathrm{~L}^{+}+\mathrm{H}^{+}, \\
\mathrm{H}_{2} \mathrm{~L}^{+} & \rightleftharpoons \mathrm{HL}+\mathrm{H}^{+}, \\
\mathrm{LH} & \rightleftharpoons \mathrm{L}^{-}+\mathrm{H}^{+} .
\end{aligned}
$$

On the basis of mathematical analysis of the potentiometric titrations, four $\mathrm{pK}_{\mathrm{a}}$ values were calculated. The exact 
description of the stepwise protonation constants of the acidity of the individual groups is not fully possible. All obtained results give, however, only the acidity sequence of particular groups in the molecule but not the exact acidity constants due to the possibility of the parallel overlapping of the deprotonation processes.

A constant corresponding with the equilibrium (1), the most likely, relates to the release of proton from the carboxylic group, which is the most acidic function of SFG. The $\mathrm{pK}$ value of this process $\left(\mathrm{pK}_{\mathrm{H}_{4} \mathrm{~L}^{3+}}^{\mathrm{H}}=3.15\right)$ is more than one log unit higher than that found in L-ornithine $[47,48]$, most probably due to electrostatic interaction with the solvent, with eventual formation of a hydrogen bond between the carboxyl group and water molecules. It should be mentioned that purine nitrogen can be involved in the formation of hydrogen bond with carboxyl hydroxylic group $\left(\mathrm{OH} \cdots \cdots \mathrm{N}_{7}\right)$. However, this explanation is valid in the case of anti conformation for $\mathrm{H}_{4} \mathrm{~L}^{3+}$ species only. As a matter of fact, computational studies concerning conformation of free-SFG indicate that, in the case of $\mathrm{H}_{4} \mathrm{~L}^{3+}$ syn, conformation predominates (Table 2, Figure 2, structure II), thus increasing the probability of occurrence of an intramolecular hydrogen bond with the protonated $\mathrm{N}_{1}$ atom. Such situation would have the reflection in the lower- $\mathrm{pK}_{\mathrm{a}}$ value of either $\mathrm{OH}_{\mathrm{COOH}}$ or $\mathrm{N}_{1}\left(\mathrm{H}^{+}\right)$, however, is not observed in any of these cases. Therefore, the presence of the intermolecular hydrogen bond between solvent water molecule and $-\mathrm{OH}$ group is proposed.

The second $\mathrm{pK}_{\mathrm{a}}$ value (3.83, Table 1, equilibrium (2)) belongs to $\mathrm{N}_{1}$ of the adenine moiety and is very close to the values obtained for adenine monophosphates $\left(\mathrm{pK}_{A M P^{\prime} s}^{H}=\right.$ $3.84[49,50])$. However, it is interestingly higher than that in the case of adenosine (3.61 [45]), in spite of the presence of a bipositive charge within the ornithine residue. Again, a macrochelate-like electrostatic interaction between the carboxyl (deprotonated) and protonated $\mathrm{N}_{1}$ nitrogen$\mathrm{N}_{1}\left(\mathrm{H}^{+}\right)$suggests that the syn conformer of SFG is preferred. Indeed, theoretical studies (see Figure 2, structure IV, and Table 2) indicate that, for this case (as well as for $\mathrm{H}_{4} \mathrm{~L}^{3+}$ ), the syn conformation prevails and the stabilizing intermolecular hydrogen bonds between $\mathrm{O}_{\mathrm{COO}}{ }^{-} \cdots \cdots \mathrm{H}_{\mathrm{H}_{2} \mathrm{O}}$ and $\mathrm{O}_{\mathrm{H}_{2} \mathrm{O}} \cdots \cdots \mathrm{H}\left(\mathrm{N}_{1}\right)^{+}$are present. As a result, an outersphere macrochelate is formed (conformation $\mathrm{V}$ in Figure 2), with consequent shift of $\mathrm{N}_{1}$ nitrogen $\mathrm{pK}$ value. Analogous phenomena involving $\mathrm{N}_{7}$ of purine were observed during macrochelate formation in the molecules of $5^{\prime}$-ATP [51] and 5'-dGTP [52].

Next deprotonations can be attributed to the both remaining amino groups $\left(\mathrm{pK}_{\mathrm{a}}=8.35\right.$ and 9.56, equilibria (3) and (4), resp.). The first, assigned to $-\mathrm{N}_{\alpha} \mathrm{H}_{3}{ }^{+}$, is $0.4 \log$ unit lower than the corresponding value for ornithine $[47,48]$, again, as a consequence of the mentioned macrochelate formation. The second, assigned to $-\mathrm{N}_{\delta} \mathrm{H}_{3}{ }^{+}$, is significantly different from the values reported for free ornithine. Such increase in acidity is most likely caused by the presence of the adenine moiety. In fact, nucleobases have similar effects in nucleotides, namely, $\mathrm{pK}_{\mathrm{a}}$ value of the second terminal hydroxyl group in $\mathrm{AMP}\left(\mathrm{pK}_{\mathrm{H}(\mathrm{AMP})}^{\mathrm{H}}=6.21[49,50]\right)$ is lower than the corresponding unaffected value in ATP
TABLE 2: Relative Gibbs free energies, Boltzmann factors (in percent), energy of solvation, and dihedral angle defining the positions of adenine for the SFG molecules.

\begin{tabular}{|c|c|c|c|c|}
\hline & $\Delta \mathrm{G}[\mathrm{kcal} / \mathrm{mol}]$ & $\mathrm{E}_{\text {solv }}[\mathrm{kcal} / \mathrm{mol}]$ & $\%^{\mathrm{a}}$ & $\angle \mathrm{O}-\mathrm{C}-\mathrm{N}-\mathrm{C}$ \\
\hline \multicolumn{5}{|c|}{$\mathrm{H}_{4} \mathrm{~L}^{3+}$} \\
\hline I (anti) & 0.8 & -322.5 & 20 & 183 \\
\hline II $(s y n)$ & 0.0 & -325.7 & 80 & 76 \\
\hline \multicolumn{5}{|c|}{$\mathrm{H}_{3} \mathrm{~L}^{2+}$} \\
\hline III (anti) & 0.8 & -168.1 & 16 & 188 \\
\hline IV (syn) & 0.0 & -170.7 & 56 & 71 \\
\hline $\mathrm{V}$ & 0.4 & -170.8 & 28 & 55 \\
\hline \multicolumn{5}{|c|}{$\mathrm{H}_{2} \mathrm{~L}^{+}$} \\
\hline VI (anti) & 4.0 & -83.0 & 0 & 170 \\
\hline VII $(s y n)$ & 0.0 & -89.7 & 100 & 68 \\
\hline \multicolumn{5}{|c|}{$\mathrm{HL}$} \\
\hline VIII (anti) & 0.0 & -47.0 & 84 & 169 \\
\hline IX $(s y n)$ & 1.0 & -52.7 & 16 & 75 \\
\hline \multicolumn{5}{|c|}{$\mathrm{L}^{-}$} \\
\hline $\mathrm{X}($ anti) & 0.0 & -79.7 & 96 & 174 \\
\hline $\mathrm{XI}(s y n)$ & 1.9 & -87.4 & 4 & 76 \\
\hline
\end{tabular}

${ }^{\mathrm{a}}$ Values calculated from the Gibbs free energies.

$\left(\mathrm{pK}_{\left.\mathrm{H}_{2} \text { (ATP) }\right)^{2-}}^{\mathrm{H}}=6.47\right.$ [51]). Thus electron withdrawing by the adenine residue may yield the observed decrease in $\mathrm{pK}_{\mathrm{a}}$ of $-\mathrm{N}_{\delta} \mathrm{H}_{3}{ }^{+}$.

The conformational analysis performed on all the four SFG forms demonstrates that the solvent affects the relative stability of each conformer, thus indicating differences in polarity. The solute-solvent interaction depends on (i) the solute and the distributions of (ii) electronic and (iii) nuclear charge. The electrostatic free energy of solvation (see Table 2) is simultaneously dependent on total charge and polarity of the whole molecule, being the energy of hydratation, larger for ionic than for neutral molecules. The polarized solutesolvent interaction energies change from $-326 \mathrm{kcal} / \mathrm{mol}$ (for $\mathrm{H}_{4} \mathrm{~L}^{3+}$ ) to $-47 \mathrm{kcal} / \mathrm{mol}$ (for neutral $\mathrm{HL}^{ \pm}$). The increase of the total polarity of the molecule yields a corresponding decrease in the ligand-solvent interaction energy, with consequent effects on the conformation of the ligand. Such effects are indeed observed for two forms of SFG (i.e., $\mathrm{HL}^{ \pm}$and $\mathrm{L}^{-}$), and were ratified by calculating the electrostatic potentials (see supplementary data, Figure 9) of $\mathrm{HL}^{ \pm}$and $\mathrm{L}^{-}$in syn and anti conformations. The electrostatic potential of $\mathrm{HL}^{ \pm}$is of course much more positive. In the syn conformation, there are areas of negative electrostatic potential near the $-\mathrm{NH}_{2}$ group, the $\mathrm{N}_{3}$ atom of adenine, and the $-\mathrm{OH}$ group of ribose moiety, but in the anti conformation, the same areas are reduced and the potential is lower as a result of the internal $\mathrm{H}$-bond between $\mathrm{N}_{3}$ and $\mathrm{OH}$. In the syn conformation of $\mathrm{L}^{-}$, there are negative potentials in the vicinity of the $-\mathrm{NH}_{2}$ group and the $\mathrm{N}_{3}$ atom, which are quite close to each other and destabilize this conformation. The calculations show that the syn conformation displays larger electrostatic free energy of solvation than the anti one (from ca. 3 to $8 \mathrm{kcal} / \mathrm{mol}$ ). It is obvious that the equilibrium conformations 


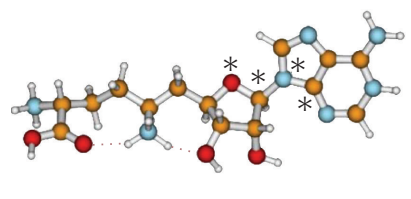

$\mathrm{I}\left(\mathrm{H}_{4} \mathrm{~L}^{3+}\right.$ anti $) \Delta G=0.8 \mathrm{kcal} / \mathrm{mol}$

(a)

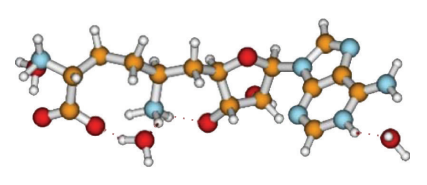

IV $\left(\mathrm{H}_{3} \mathrm{~L}^{2+}\right.$ syn $) \Delta G=0 \mathrm{kcal} / \mathrm{mol}$

(d)

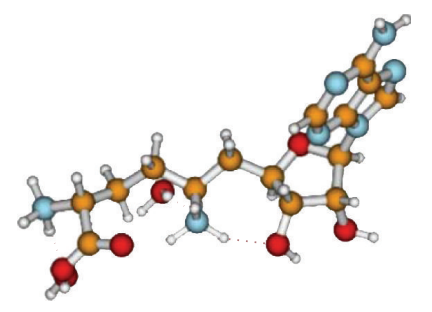

VII $\left(\mathrm{H}_{2} \mathrm{~L}^{+}\right.$syn $) \Delta G=0 \mathrm{kcal} / \mathrm{mol}$

(g)

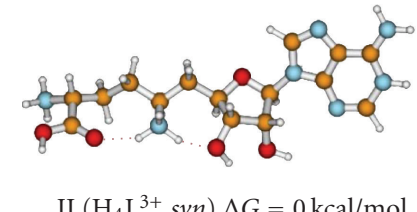

(b)

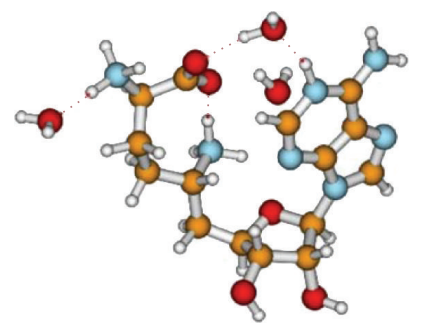

$\mathrm{V}\left(\mathrm{H}_{3} \mathrm{~L}^{2+}\right) \Delta G=0.4 \mathrm{kcal} / \mathrm{mol}$

(e)

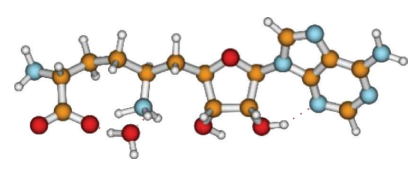

VIII (HL anti) $\Delta G=0 \mathrm{kcal} / \mathrm{mol}$

(h)

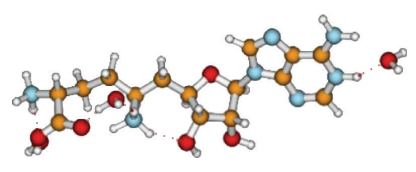

III $\left(\mathrm{H}_{3} \mathrm{~L}^{2+}\right.$ anti) $\Delta G=0.8 \mathrm{kcal} / \mathrm{mol}$

(c)

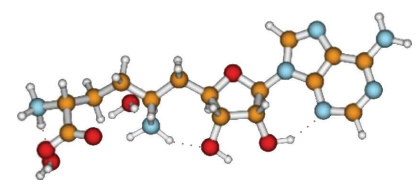

$\mathrm{VI}\left(\mathrm{H}_{2} \mathrm{~L}^{+}\right.$anti $) \Delta G=4 \mathrm{kcal} / \mathrm{mol}$

(f)

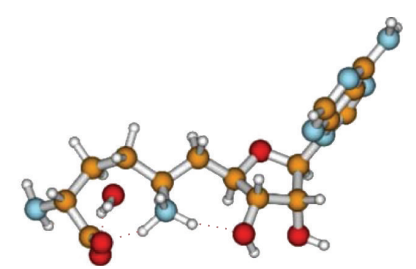

IX (HL syn) $\Delta G=1 \mathrm{kcal} / \mathrm{mol}$

(i)

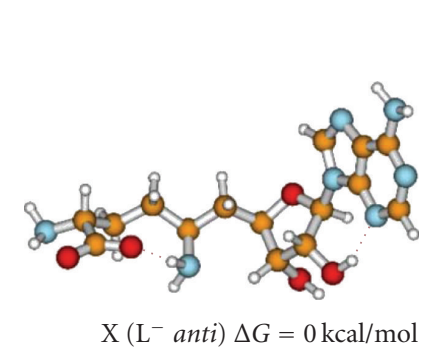

(j)

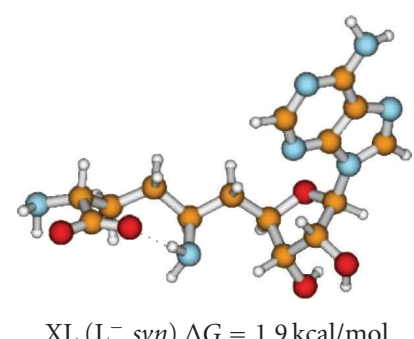

(k)

FIGURE 2: Conformations of free SFG molecule in various protonation states. The rotation angle of adenine is marked with asterisks.

of nucleotides are affected by solvent effects and particularly by intramolecular H-bonds, as reported previously [53]. In the calculations related to SFG, the syn conformation is favored in all cases, but for $\mathrm{HL}$ and $\mathrm{L}^{-}$, the solvation energies indicate differences in polarity.

The rotational barrier of adenine moiety was calculated only for $\mathrm{H}_{4} \mathrm{~L}^{3+}$ at $1.4 \mathrm{kcal} / \mathrm{mol}$ for syn-antirotation and $2.8 \mathrm{kcal} / \mathrm{mol}$ for anti-syn rotation. This value is very close to the energybarrier for syn-anti conformation (1.43$1.19 \mathrm{kcal} / \mathrm{mol}$ ) estimated for cytidine derivatives in aqueous solution at $25^{\circ} \mathrm{C}[54,55]$. The calculated anti-syn barrier for fully protonated SFG is over $1 \mathrm{kcal} / \mathrm{mol}$ larger than that measured for cytidine derivatives.

The conformations obtained for the diversely protonated forms of SFG are shown in Figure 2. The relative Gibbs free- energy values obtained after addition of the thermal corrections, and the energies of solvation are collected in Table 2, together with the dihedral angle defining the rotation of adenine (atoms defining the rotation angle are marked with asterisks in Figure 2). Boltzmann factors (in percentage) calculated from free energies are also shown in Table 2.

\subsection{Copper(II) coordination pattern to sinefungin}

The process of copper(II) binding by sinefungin as well as similar agents representing the combination of nucleosides and aminoacids, may have biological consequences. As we have already provided, the $\mathrm{Cu}(\mathrm{II})$-sinefungin complexes may be regarded as genotoxic compounds since they cleave DNA with the hydroxyl radicals-based mechanism [43]. DNA 
degradation proceeds even in the presence of physiologically widespread antioxidants (glutathione, ascorbate), what additionally confirms high toxicity of the studied complexes. Moreover, these studies presented sinefungin as a ligand able to compete for $\mathrm{Cu}$ (II) coordination with cellular substances. This result prompted us to undertake current studies aimed to resolve the complexation equilibria in $\mathrm{Cu}(\mathrm{II})$-sinefungin system.

The potentiometric titrations of the $\mathrm{Cu}(\mathrm{II})-\mathrm{SFG}$ complex allowed to calculate the stability constants of the two mononuclear species, $\mathrm{CuHL}^{2+}$ and $\mathrm{CuH}_{2} \mathrm{~L}_{2}{ }^{2+}$, the formation of which corresponds to equilibria (5) and (6):

$$
\begin{aligned}
\mathrm{Cu}^{2+}+\mathrm{HL} & \rightleftharpoons \mathrm{CuHL}^{2+}, \\
\mathrm{Cu}^{2+}+2 \mathrm{HL} & \rightleftharpoons \mathrm{CuH}_{2} \mathrm{~L}_{2}{ }^{2+} .
\end{aligned}
$$

The obtained values are reported in Table 1 and compared to the literature data related to ornithine.

Besides the two mentioned species, the eventual formation of $\mathrm{CuH}_{4} \mathrm{~L}^{5+}, \mathrm{CuH}_{3} \mathrm{~L}^{4+}$, and $\mathrm{CuH}_{2} \mathrm{~L}^{3+}$ may be discussed. In the $\mathrm{CuH}_{4} \mathrm{~L}^{5+}$ complex, $\mathrm{Cu}(\mathrm{II})$ should bind at $\mathrm{N}_{7}$ of the adenine ring, what is quite improbable because of the electrostatic repulsion of the positive charge at the $\mathrm{N}_{1}(\mathrm{H})^{+}$nitrogen. In the $\mathrm{CuH}_{3} \mathrm{~L}^{4+}$ form, $\mathrm{Cu}$ (II) may bind to the carboxylate, but the $\log K$ of this complex is too low to be detected by potentiometry. The case of $\mathrm{CuH}_{2} \mathrm{~L}^{3+}$ is somehow different since $\mathrm{Cu}$ (II) may directly and simultaneously bind at $\mathrm{N}_{1}$ (or $\mathrm{N}_{7}$ ) and the carboxylate. Potentiometric data do not allow to extract the stability constant for this complex, but the differential UV spectra (Figure 3) display a band at ca. $260 \mathrm{~nm}$, which is consistent with the interaction of the adenine ring with $\mathrm{Cu}(\mathrm{II})$ [56]. Experimental data are not sufficient to demonstrate any stabilizing interaction between the metal-coordinated exocyclic nitrogen donor atom and the $\mathrm{COO}^{-}$group. However, DFT calculations supported the occurrence of a complex, where $\mathrm{Cu}$ (II) interacts with the carboxylate through one of the five metal-bounded water molecules (outer-sphere macrochelate). The optimized lowest energy structure of $\mathrm{CuH}_{2} \mathrm{~L}^{3+}$ is shown in Figure 4, while bond distances and the $\mathrm{O}-\mathrm{C}-\mathrm{N}-\mathrm{C}$ angle defining the position of the adenine group are collected in Table 3 (structure XII). The stability of this complex is higher in calculations implying solvent molecules. Hence we can conclude that the complex in this particular structure can occur in solution. The remaining proposals for the $\mathrm{CuH}_{2} \mathrm{~L}^{3+}$ complexes are much less stable, and thus they are not included in Table 3 and Figure 4.

\section{(i) $\mathrm{CuHL}^{2+}$ complexes}

The $\mathrm{CuHL}^{2+}$ species, which dominates between $\mathrm{pH} 5.0$ and $\mathrm{pH} 6.0$ (Figure 5), involves $\mathrm{Cu}$ (II) binding at the $\alpha$ amino group and the carboxylate, with consequent formation of a stable 5-membered chelate ring similar to the $\mathrm{Cu}$ (II)-ornithine system $[47,48]$. Participation of one nitrogen donor in the metal coordination sphere is ratified by the localization of $\mathrm{d}-\mathrm{d}$ bands on $\mathrm{CD}$ and $\mathrm{UV}-\mathrm{Vis}$ spectra (see Figure 5) as well as the values of EPR parameters $\left(A_{I I}=160 \mathrm{G}, g_{\mathrm{II}}=2.31\right)$ (Figure 6$)$. On the parallel part

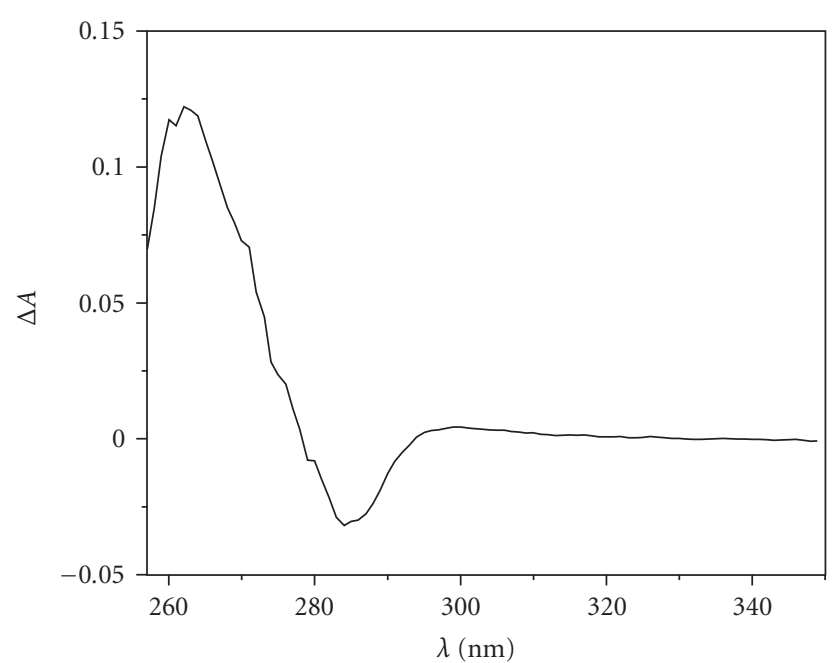

FIgure 3: The differential UV spectrum for the Cu(II)-SFG system obtained by subtraction of the spectrum at $\mathrm{pH} 3.45$ from the spectrum at $\mathrm{pH} 4.57$.

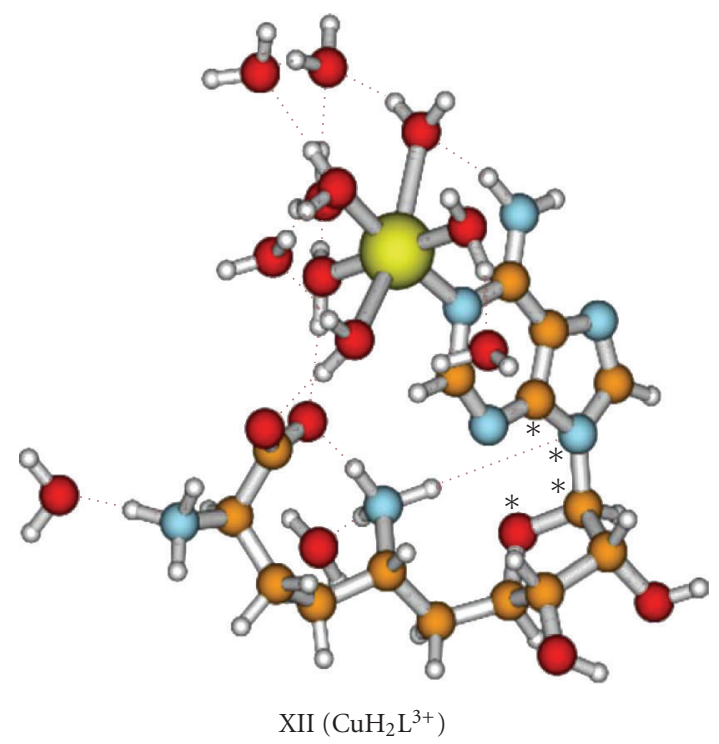

FIgUre 4: The lowest energy structure of $\mathrm{CuH}_{2} \mathrm{~L}^{3+}$ complex. The angle $\mathrm{O}-\mathrm{C}-\mathrm{N}-\mathrm{C}$ defining the position of adenine group is marked with asterisks.

of the EPR spectrum obtained at pH 5.6 apart from the signals corresponding to the $\mathrm{CuHL}^{2+}$ species, also signals derived from the presence of bis-complex with stoichiometry $\mathrm{CuH}_{2} \mathrm{~L}_{2}{ }^{2+}$ are observed. However, appropriate parameters of the hyperfine splitting can be clearly attributed to the corresponding complex species. Taking into account that, at these conditions, not all copper(II) ions are complexed by SFG molecules, signals for $\mathrm{Cu}$ (II) aqua ion are also identified (asterisk in Figure 6). EPR results in this case well reflectthe distribution of the copper(II) forms in solution, where free metal ions coexist with both coordination species at $\mathrm{pH} 5.6$ (Figure 5). These results are consistent with the $1 \mathrm{~N}$ coordination type, although indirect outer-sphere participation of 
TABLE 3: Relative Gibbs free energies, Boltzmann factors (in percent), and selected geometrical parameters for Cu(II)-SFG complexes.

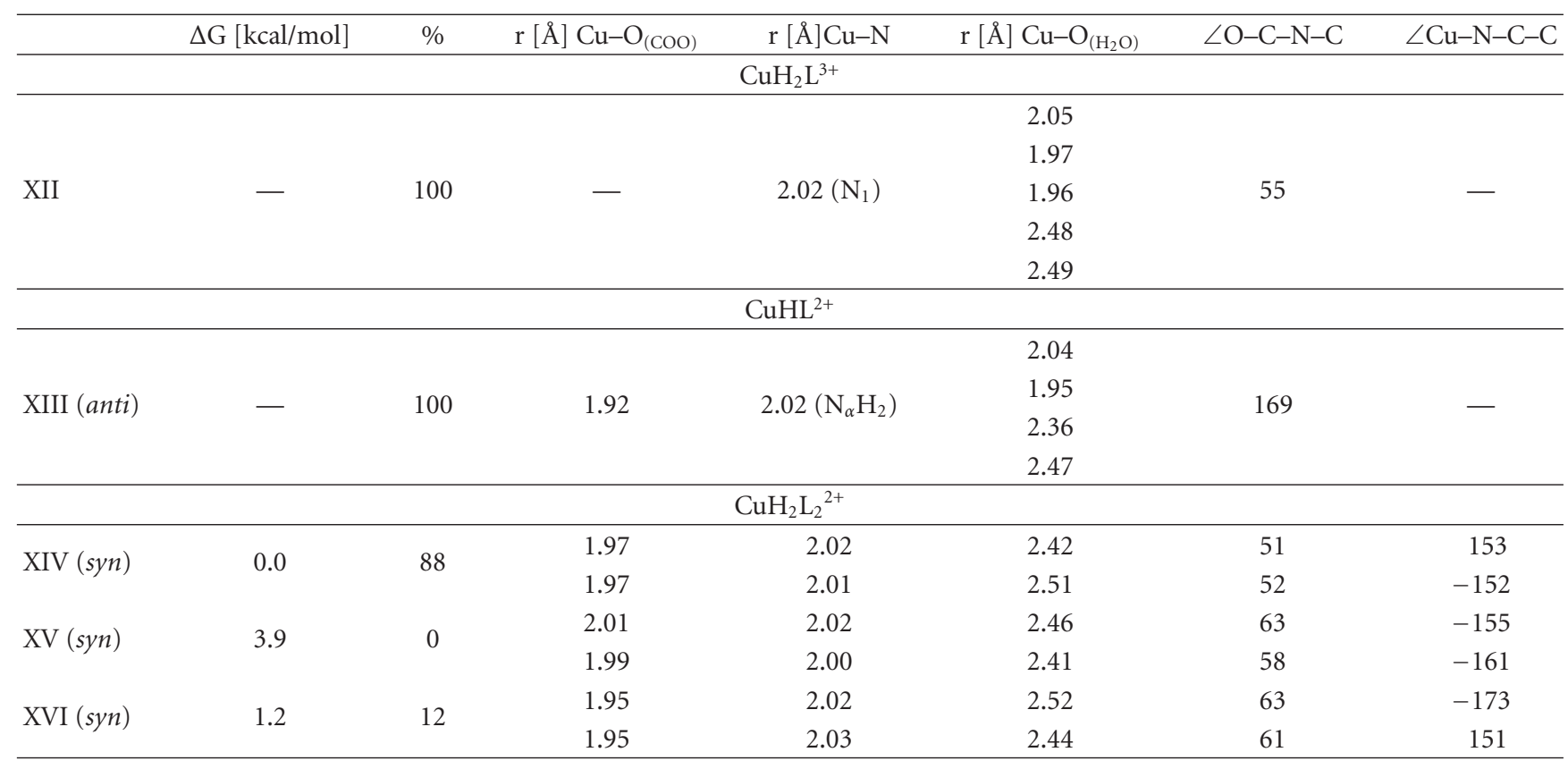

the $\mathrm{N}_{7}$ donor in the coordination process cannot be excluded [42].

The optimized geometry of the lowest-energy structure of $\mathrm{CuHL}^{2+}$ is shown in Figure 7, and the corresponding selected geometry parameters are collected in Table 3 (structure XIII). The more extended surface of the anticonformer accounts for larger solute-solvent interactions and such effect energetically favors the anti conformation in solution. In this case, the solvation energy (not shown in Table 3 ) is larger for theanticonformer. As presented in Table 3, the axial water molecules are rather loosely bound, what results in $\mathrm{Cu}-\mathrm{OH}_{2}$ distance in the range 2.3-2.5 $\AA$. The equatorial water ligands are considerably more strongly bound (the $\mathrm{Cu}-\mathrm{OH}_{2}$ distance is ca. 2.0 $\AA$ ).

\section{(ii) $\mathrm{CuH}_{2} \mathrm{~L}_{2}{ }^{2+}$ complexes}

In the $\mathrm{CuH}_{2} \mathrm{~L}_{2}{ }^{2+}$ complex, two SFG molecules are bound to the metal ion in the same way as in the previous species (i.e., by $\alpha$-amino and carboxyl groups) with formation of two stable 5-membered chelate rings. Again, this coordination mode is ratified by spectroscopic data. EPR parameters $\left(\mathrm{A}_{\mathrm{II}}=180 \mathrm{G}, \mathrm{g}_{\mathrm{II}}=2.26\right)$ reveal the presence of two nitrogen donors (Figure 6) and the changes in CD and UV-Vis spectra (see Figures 5(a), 5(b), resp.) indicate the $\left\{2 \times \mathrm{NH}_{2}, 2 \times\right.$ $\left.\mathrm{O}_{\mathrm{COO}}{ }^{-}\right\}$coordination mode. Participation of $\mathrm{N}_{1} / \mathrm{N}_{7}$ atom in the coordination may occur through outer-sphere interactions with axially coordinated water molecules. However, taking into account that syn conformation of adenine moiety dominates (see DFT results), we can suppose that $\mathrm{N}_{1}$ nitrogen interacts indirectly with $\mathrm{Cu}(\mathrm{II})$ ion.

The proposed coordination mode, that is, two carboxylate oxygen atoms, two $\alpha$-amino group, and two axial water molecules, leading to six-coordinated $\mathrm{Cu}$ (II) ion, was taken into account for calculations. The isomers with $\mathrm{O}-\mathrm{Cu}-\mathrm{O}$ and $\mathrm{N}-\mathrm{Cu}-\mathrm{N}$ trans and cis arrangement were also considered in the optimization with the former ones appearing to be more stable. The geometry optimization was performed for the syn and anti conformations of the adenine group, and the stability was found somehow higher with the syn rather than the anti conformation. The three most-stable syn conformers are reported in Figure 8. The corresponding free energies, Boltzmann factors and selected structural parameters, are collected in Table 3. The $\mathrm{Cu}-\mathrm{N}-\mathrm{C}-\mathrm{C}$ angle defines the conformation of the $\mathrm{COO}-\mathrm{CH}_{2}-\mathrm{N}_{\alpha} \mathrm{H}_{2}$ fragment coordinated to copper(II) ion. The angles of the two HL ligands are of the same or opposite sign, what determines the geometry around metal ion: $C_{2}$ local symmetry in the case of identical sign and $C_{i}$ in the other case. The formation of intramolecular hydrogen bonds can be noted in all conformers: between $-\mathrm{NH}_{3}{ }^{+}$ and carboxylate, $-\mathrm{NH}_{3}{ }^{+}$and ribose moiety (structures XIVXVI, Figure 8), as well as $-\mathrm{NH}_{3}{ }^{+}$and $\mathrm{N}_{3}$ (structure XIV, Figure 8). The formation of a hydrogen bond between the $-\mathrm{N}_{\delta} \mathrm{H}_{3}{ }^{+}$group and the $\mathrm{N}_{3}$ nitrogen atom of adenine moiety is only found for structure XIV. This may be a result of different ornithine carbon chain conformation as compared with the remaining structures. In this conformation, adenine and $-\mathrm{NH}_{3}{ }^{+}$are close to each other.

The syn-anti equilibrium of adenine in both free and complexed SFG depends significantly on solvation effects and formation of intra and intermolecular $\mathrm{H}$-bonds in such a manner that small perturbations may result in the meaningful changes. Solvent effects have been found to stabilize the syn conformation of adenine in almost all studied systems. However, comparison of the structures I-XVI shows that other factors, like $\mathrm{Cu}$ (II) coordination mode, also influence 


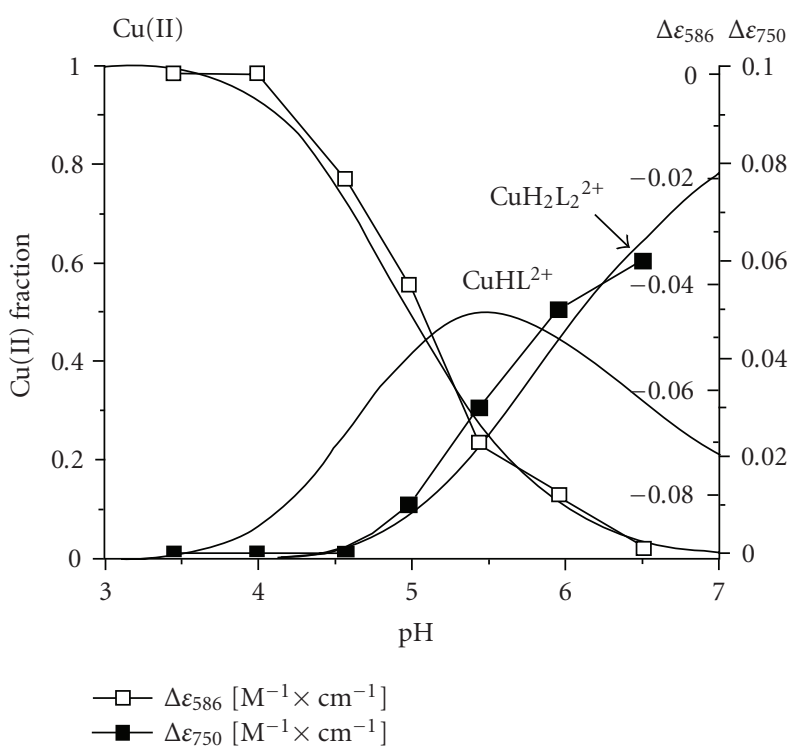

(a)

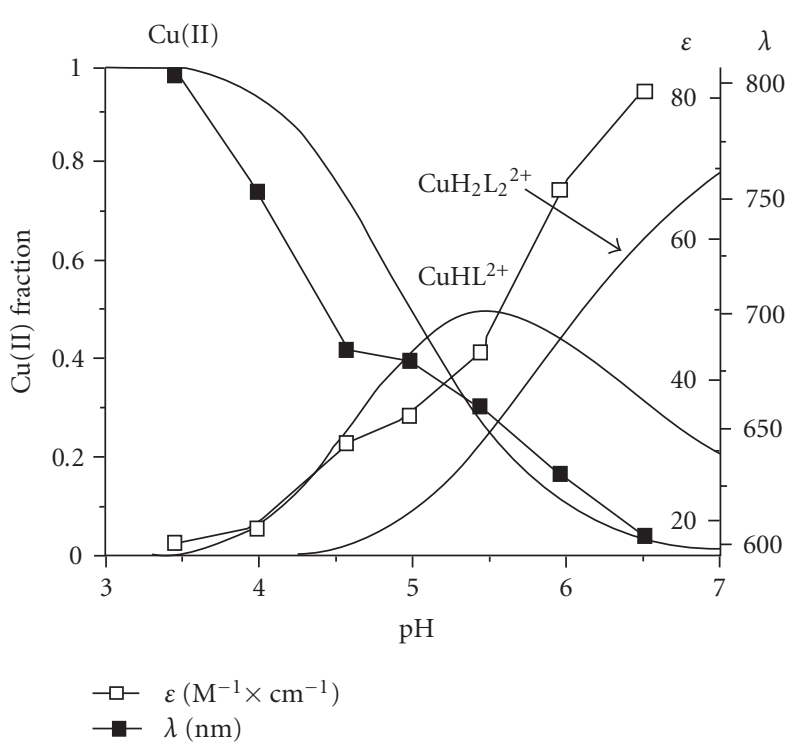

(b)

FIGURE 5: The pH-dependent courses of complexes concentrations and the (a) CD and (b) UV-Vis spectra parameters overlaid.

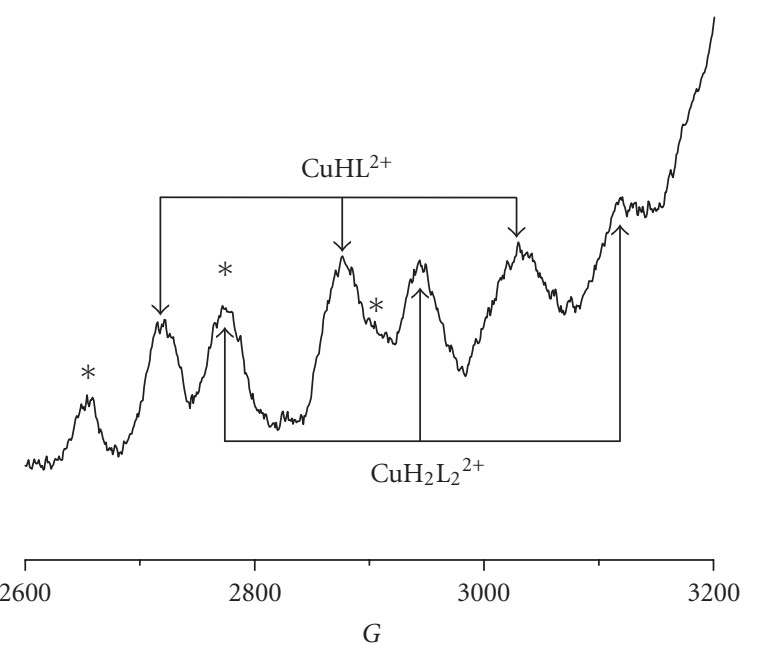

Figure 6: The EPR spectra for the Cu(II)-SFG system at pH 5.6. Signals for complex species are indicated by arrows and signals for $\mathrm{Cu}(\mathrm{II})$ aqua ion are depicted with asterisks.

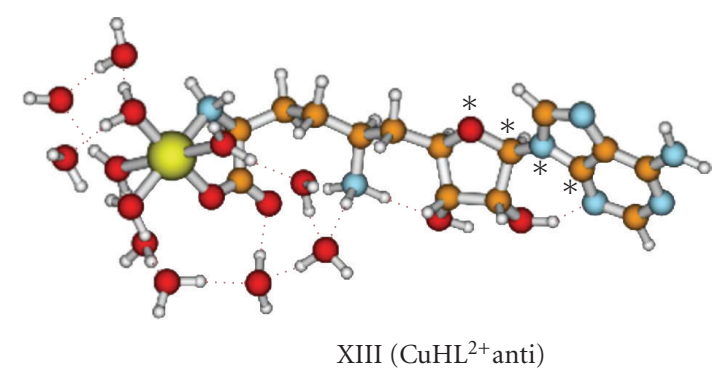

FIgUre 7: The lowest energy structure of $\mathrm{CuHL}^{2+}$ complex. The rotation angle of adenine is marked with asterisks. the relative syn-anti stability. Isomerism related to the presence of $\mathrm{N}_{1} / \mathrm{N}_{7}$ in the coordination sphere, in the case of both $\mathrm{CuHL}^{2+}$ and $\mathrm{CuH}_{2} \mathrm{~L}_{2}{ }^{2+}$ species, results from the formation of open and close complexes divided into outer- and innersphere, and does not allow ascribing the spectroscopic parameters to particular complexes.

Molecular features of the complexes that include fully deprotonated SFG molecules in mono- and bis-complexes are difficult to be obtained due to the $\mathrm{Cu}(\mathrm{OH})_{2}$ precipitation above $\mathrm{pH} 7$.

\section{CONCLUSIONS}

Since $\mathrm{Cu}(\mathrm{II})$ coordination may become an important factor of sinefungin-induced cellular toxicity, the stability constants for the $\mathrm{Cu}(\mathrm{II})$-sinefungin system were evaluated. They were compared to the analogous values obtained for the $\mathrm{Cu}(\mathrm{II})$ ornithine species and appeared to be slightly lower. Despite the decrease in stability of cupric complexes of sinefungin, this ligand offers higher diversity of potential binding sites for copper(II) coordination process. Since the potentiometric titrations did not yield any data above $\mathrm{pH} 7$ due to precipitation, it was not possible to describe the studied system at the physiological $\mathrm{pH}$. However, we evaluated that, at $\mathrm{pH} 7$, copper ions are completely bound by sinefungin molecules. In these conditions, two kinds of complexes coexist in water solution. They share the same coordination pattern of sinefungin (ornithine donor atoms), but the difference is in the amount of ligands engaged in complexation. Furthermore, DFT studies suggest that $\mathrm{N}_{1}$ nitrogen atom from adenine moiety also participates in the coordination. The calculations results propose that this process occurs through water molecule (outer-sphere). The syn-anti conformation equilibrium in complexed and free mboxsinefungin 


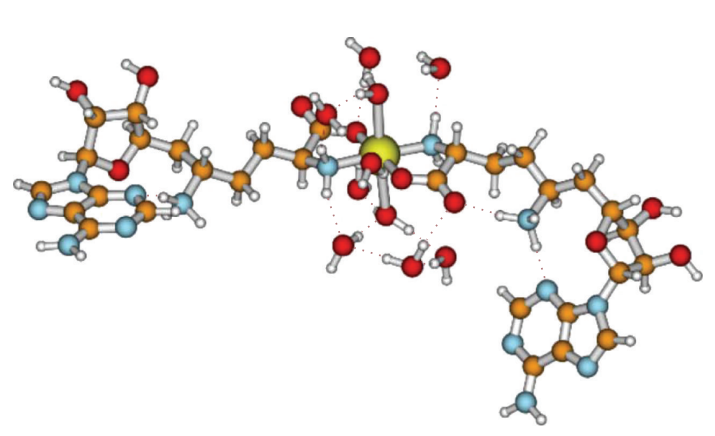

$\mathrm{XIV}\left(\mathrm{CuH}_{2} \mathrm{~L}_{2}{ }^{2+}\right.$ syn $) \Delta G=0 \mathrm{kcal} / \mathrm{mol}$

(a)

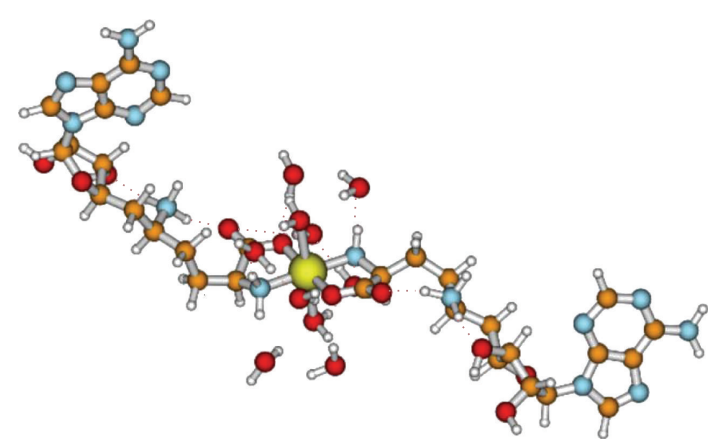

$\mathrm{XV}\left(\mathrm{CuH}_{2} \mathrm{~L}_{2}{ }^{2+}\right.$ syn $) \Delta G=3.9 \mathrm{kcal} / \mathrm{mol}$

(b)

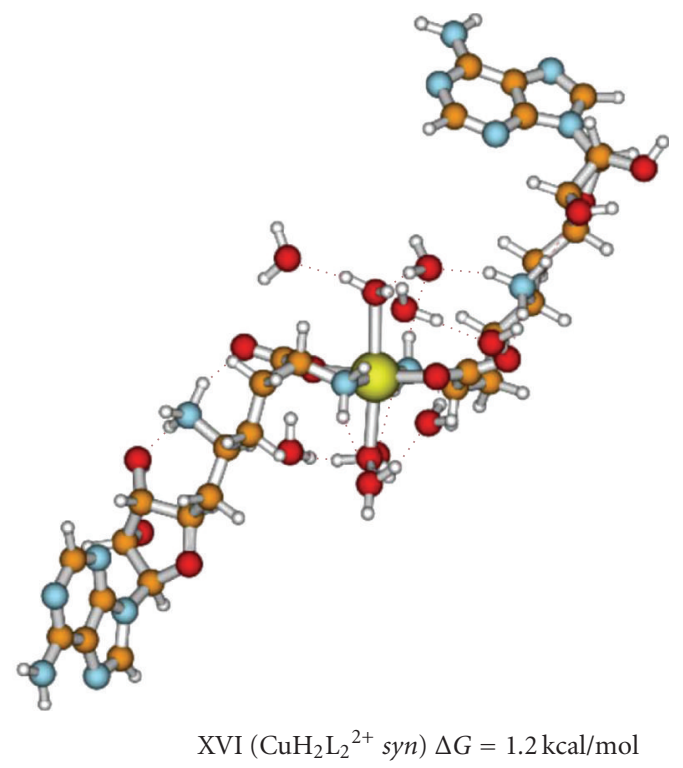

(c)

FIgURE 8: The lowest energy structures of $\mathrm{CuH}_{2} \mathrm{~L}_{2}{ }^{2+}$ in syn conformation. The angle $\mathrm{Cu}-\mathrm{N}-\mathrm{C}-\mathrm{C}$ defining the conformation of SFG at the copper center is marked with asterisks.

depends on the protonation state and on the number of intramolecular hydrogen bonds.

\section{EXPERIMENTAL SECTION}

\subsection{Materials}

Sinefunginand $\mathrm{HNO}_{3}$ were purchased from Sigma Chemical Co.(MO, USA). $\mathrm{NaClO}_{4}, \mathrm{Cu}\left(\mathrm{ClO}_{4}\right)_{2}, \mathrm{KNO}_{3}$, and $\mathrm{NaOH}$ were obtained from Merck KGaA, (Darmstadt, Germany). Ethanediol was purchased from POCH S.A. (Gliwice, Poland).

\subsection{Potentiometric titrations}

Potentiometric titrations of sinefungin and its complexes with $\mathrm{Cu}(\mathrm{II})$ ions in the presence of $0.1 \mathrm{M} \mathrm{KNO}_{3}$ were performed at $25^{\circ} \mathrm{C}$, within the $\mathrm{pH}$ range $2.8-10.5$ (Molspin automatic titrator, Molspin Ltd, Newcastle upon Tyne, UK) with $\mathrm{CO}_{2}$-free $0.09997 \mathrm{M} \mathrm{NaOH}$ as titrant. Changes in $\mathrm{pH}$ were monitored with a combined glass- $\mathrm{Ag} / \mathrm{AgCl}$ electrode (Russell pH Ltd., ThermoRussell CMAW 711, Fife, UK), calibrated daily in hydrogen ion concentrations by $\mathrm{HNO}_{3}$ titrations [57]. Sample volumes of $2 \mathrm{ml}$ were used. Ligand concentration was $0.7 \mathrm{mM}$, and a metal to ligand molar ratio of $1: 2$ was used. These data were analyzed using SUPERQUAD program [58]. Standard deviations computed by Superquad refer to random errors only.

\subsection{Electronic absorption spectroscopy}

The electronic absorption spectra were recorded at $25^{\circ} \mathrm{C}$ on a Cary 50 Bio spectrophotometer (Varian Inc., CA, USA) over the spectral range $190-900 \mathrm{~nm}$, in 1 or $0.1 \mathrm{~cm}$ cells. The metal to ligand molar ratio was $1: 2$, and the concentration of the former one was $1.5 \mathrm{mM}$. The measurements were done in the presence of $0.1 \mathrm{M} \mathrm{NaClO}_{4}$, due to its transparency in far UV. 


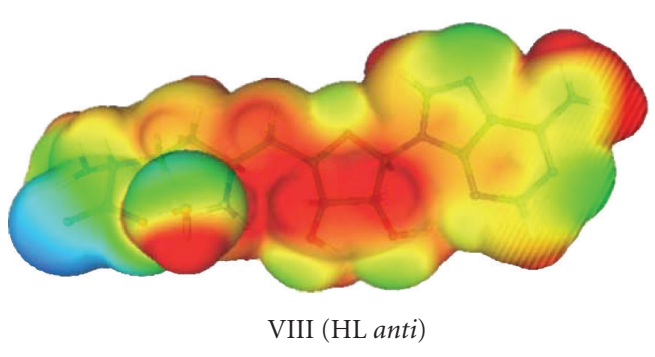

(a)

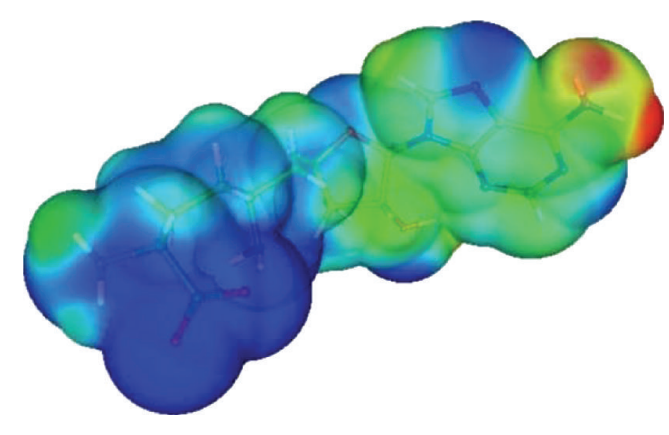

$\mathrm{X}\left(\mathrm{L}^{-}\right.$anti)

(c)

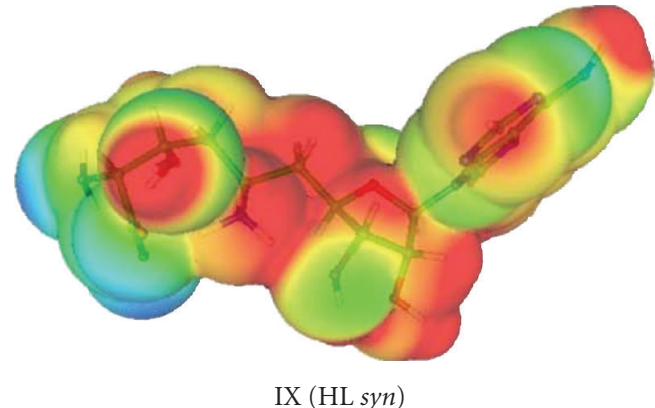

(b)

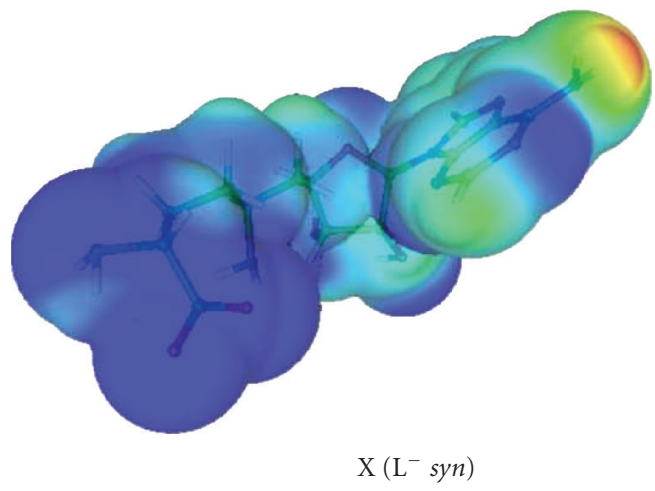

(d)

FIGURE 9: Electrostatic potentials of $\mathrm{HL}$ and $\mathrm{L}^{-}$in the syn and anti conformations. The potential values are in the range from -0.012 [a.u.] (blue) to 0.05 [a.u.] (red).

\subsection{Circular dichroism spectroscopy}

The CD spectra were recorded at the same conditions as UVVis measurements, on the Jasco J-715 spectropolarimeter (JASCO, Japan Spectroscopic Co., Hiroshima, Japan), over the ranges $190-350 \mathrm{~nm}$, using $0.1 \mathrm{~cm}$ cells, and $300-800 \mathrm{~nm}$, using $5 \mathrm{~cm}$ cells. The metal-ligand molar ratio and the concentration were the same as in UV-Vis measurements. Spectra were expressed in terms of $\Delta \varepsilon=\varepsilon_{1}-\varepsilon_{\mathrm{r}}$, where $\varepsilon_{1}$ and $\varepsilon_{\mathrm{r}}$ are molar absorption coefficients for left and right circularly polarized light, respectively.

\subsection{Electron paramagnetic resonance}

The spectra of the $\mathrm{Cu}$ (II) complex with sinefungin were recorded at $77 \mathrm{~K}$ on a Bruker ESP $300 \mathrm{E}$ spectrometer (Karlsruhe, Germany) at the X-band frequency $(9.3 \mathrm{GHz})$. Ethanediol-water $(1: 2)$ was used as a solvent to obtain homogeneity of frozen samples. Samples concentrations were the same as those applied in other spectroscopic measurements.

\subsection{Molecular modeling}

All calculations were performed without any symmetry constraints with the use of Gaussian 03 program [59]. The density functional theory (DFT) method was used with the B3LYP hybrid functional [60-62]. In the calculations, the
PCM solvent model was used [63], with water as the solvent. In the first step, geometries optimization was performed in the basis $6-31 \mathrm{G}^{*}$ for $\mathrm{C}, \mathrm{N}, \mathrm{O}, \mathrm{H}$ atoms, and $6-311 \mathrm{G}^{*}$ for copper ion. The vibrational frequencies were calculated every time to confirm that the obtained structures correspond to local minima on the potential energy surface. Furthermore, the thermal corrections, for all optimized considered structures, were calculated. The obtained structures were used as inputs, and the energies of the optimized geometries were recalculated with the PCM model in a larger basis sets: 6-311+ $\mathrm{G}^{*}$ for $\mathrm{N}, \mathrm{C}, \mathrm{O}, \mathrm{H}$ in the case of free sinefungin molecule, $6-$ $311+\mathrm{G}^{*}$ for $\mathrm{Cu}, 6-31+\mathrm{G}^{*}$ for $\mathrm{N}, \mathrm{C}, \mathrm{O}$, and $6-31+\mathrm{G}^{* *}$ for $\mathrm{H}$ in the case of copper complexes. The data in tables contain values calculated with larger basis. The molecular structures were depicted by the program MOLDEN [64], and electrostatic potentials were drawn by the program gOpenMol [65].

Conformations of sinefungin in various protonation states were investigated, namely, $\mathrm{H}_{4} \mathrm{~L}^{3+}, \mathrm{H}_{3} \mathrm{~L}^{2+}, \mathrm{H}_{2} \mathrm{~L}^{+}, \mathrm{HL}^{ \pm}$, and $\mathrm{L}^{-}$, where $\mathrm{L}^{-}$stands for the fully deprotonated SFG molecule. In each case, optimization was done for the syn and ant $i$ conformations of the adenosine moiety. In the cases of $\mathrm{H}_{3} \mathrm{~L}^{2+}, \mathrm{H}_{2} \mathrm{~L}^{+}$, and $\mathrm{HL}^{ \pm}$, water molecules were added in the vicinity of $-\mathrm{COO}^{-}$and neighboring $-\mathrm{NH}_{3}{ }^{+}$groups to prevent proton jumps between them, whereas the calculations for $\mathrm{H}_{4} \mathrm{~L}^{3+}$ and $\mathrm{L}^{-}$were performed without additional water molecules since the mentioned proton jump is not observed.

Geometry optimization of $\mathrm{CuH}_{2} \mathrm{~L}^{3+}$ was performed for the coordination modes consistent with the experimental 
data, involving copper(II) coordination to the carboxylate oxygen and adenine nitrogen. Twelve water molecules were used in the optimization. In the considered structures, $\mathrm{Cu}$ (II) ion is coordinated by five or four water molecules. Water molecules, not entering the coordination sphere, are located around this sphere or $\mathrm{H}$-bonded to polar groups in the SFG molecule. Also, the calculations for $\mathrm{CuHL}^{2+}$ complex species were performed with twelve water molecules. Four water molecules are directly bound to $\mathrm{Cu}(\mathrm{II})$, the remaining ones are located around the first coordination sphere. Syn and anti conformations of adenine were considered. For the $\mathrm{CuH}_{2} \mathrm{~L}_{2}{ }^{2+}$, eight water molecules were included around the first coordination sphere of copper ion. Other six-coordinated complexes were also considered, in which, copper is additionally bound by $\mathrm{N}_{7}$ or $\mathrm{N}_{1}$ of adenine, either directly (inner-sphere) or indirectly (outer-sphere) through a water molecule.

\section{ACKNOWLEDGMENTS}

The Gaussian03 calculations were carried out in the Wrocław Center for Networking and Supercomputing, WCSS, Wrocław, Poland, under calculational Grant no. 51/96. This work was financially supported by the Polish State Committee for Scientific Research (KBN), Grant no. 4 T09A 17925.

\section{REFERENCES}

[1] H. Sigel, "Intramolecular equilibria in metal ion complexes of artificial nucleotide analogues with antiviral properties. A case study," Coordination Chemistry Reviews, vol. 144, pp. 287-319, 1995.

[2] H. Sigel, Metal Ions in Biological Systems, vol. 8, Marcel Dekker, New York, NY, USA, 1979.

[3] A. Holý, I. Votruba, M. Masojídková, et al., "6-[2(Phosphonomethoxy)alkoxy]pyrimidines with antiviral activity," Journal of Medicinal Chemistry, vol. 45, no. 9, pp. 19181929, 2002.

[4] R. S. Gordee and T. F. Butler, "A9145, a new adenine containing antifungal antibiotic. II. Biological activity," Journal of Antibiotics, vol. 26, no. 8, pp. 466-470, 1973.

[5] M. Geze, P. Blanchard, J. L. Fourrey, and M. Robert-Gero, "Synthesis of sinefungin and its $\mathrm{C}-6$ ' epimer," Journal of the American Chemical Society, vol. 105, no. 26, pp. 7638-7640, 1983.

[6] P. Brasseur, D. Lemeteil, and J.-J. Ballet, "Curative and preventive anticryptosporidium activities of sinefungin in an immunosuppressed adult rat model," Antimicrobial Agents and Chemotherapy, vol. 37, no. 4, pp. 889-892, 1993.

[7] B. L. Mirkin, R. F. O’Dea, and H. P. Hogenkamp, “Cytotoxic action of adenosine nucleoside and dialdehyde analogues on murine neuroblastoma in tissue culture: structure-activity relationships," Cancer Research, vol. 47, no. 14, pp. 3650-3655, 1987.

[8] C. S. G. Pugh, R. T. Borchardt, and H. O. Stone, "Sinefungin, a potent inhibitor of virion mRNA (guanine-7-)methyltransferase, mRNA (nucleoside $-2^{\prime}-$ )-methyltransferase, and viral multiplication," Journal of Biological Chemistry, vol. 253, no. 12, pp. 4075-4077, 1978.

[9] M. Vedel, F. Lawrence, M. Robert-Gero, and E. Lederer, "The antifungal antibiotic sinefungin as a very active inhibitor of methyltransferases and of the transformation of chick embryo fibroblasts by Rous Sarcoma virus," Biochemical and Biophysical Research Communications, vol. 85, no. 1, pp. 371-376, 1978.

[10] M. Konishi, M. Kimeda, H. Tsukiura, et al., "Oxamicetin, a new antibiotic of bacterial origin. I. Production, isolation and properties," Journal of Antibiotics, vol. 26, no. 12, pp. 752-756, 1973.

[11] H. Osada and K. Isono, "Occurrence of an ascamycin dealanylating enzyme, Xc-aminopeptidase, in mammalian cell membranes and susceptibility to ascamycin," Journal of Antibiotics, vol. 39, no. 2, pp. 286-293, 1986.

[12] K. Isono, M. Uramoto, H. Kusakabe, et al., "Dealanylascamycin, nucleoside antibiotics from Streptomyces sp," Journal of Antibiotics, vol. 37, no. 6, pp. 670-672, 1984.

[13] M. Uramoto, K. Kobinata, K. Isono, et al., "Chemistry of the neopolyoxins, pyrimidine and imidazoline nucleoside peptide antibiotics," Tetrahedron, vol. 38, no. 11, pp. 1599-1608, 1982.

[14] H. Seto, I. Yamaguchi, N. Ötake, and H. Yonehara, "Biogenesis of blasticidin S," Tetrahedron Letters, vol. 7, no. 32, pp. 37933799, 1966.

[15] G. Wu and S. M. Morris Jr., "Arginine metabolism: nitric oxide and beyond," Biochemical Journal, vol. 336, no. 1, pp. 1-17, 1998.

[16] R. C. Greene, "Incorporation of the carbon chain of methionine into spermidine," Journal of the American Chemical Society, vol. 79, no. 14, p. 3929, 1957.

[17] H. Tabor, S. M. Rosenthal, and C. W. Tabor, "The biosynthesis of spermidine and spermine from putrescine and methionine," Journal of Biological Chemistry, vol. 233, no. 4, pp. 907914, 1958.

[18] V. Zappia and A. E. Pegg, Eds., Progress in Polyamine Research Plenum, Plenum Press, New York, NY, USA, 1988.

[19] L. Łomozik, "Bioinorganic chemistry," in Handbook of MetalLigand Interactions in Biological Fluids, G. Berthon, Ed., vol. 1, Marcel Dekker, New York, NY, USA, 1995.

[20] S. S. Cohen, Introduction to the Polyamines, Prentice-Hall, Englewood Cliffs, NJ, USA, 1971.

[21] J. Jänne, H. Pösö, and A. Raina, "Polyamines in rapid growth and cancer," Biochimica et Biophysica Acta, vol. 473, no. 3-4, pp. 241-293, 1978.

[22] N. E. Newton and M. M. Abdel-Monem, "Inhibitors of polyamine biosynthesis. 4 . Effects of $\alpha$-methyl- $( \pm)$-ornithine and methylglyoxal bis(guanylhydrazone) on growth and polyamine content of L1210 leukemic cells of mice," Journal of Medicinal Chemistry, vol. 20, no. 2, pp. 249-253, 1977.

[23] P. Bey, C. Danzin, V. Van Dorsselaer, P. Mamont, M. Jung, and C. Tardif, "Analogues of ornithine as inhibitors of ornithine decarboxylase. New deductions concerning the topography of the enzyme's active site," Journal of Medicinal Chemistry, vol. 21, no. 1, pp. 50-55, 1978.

[24] G. Sosnovsky, J. Lukszo, E. Gravela, and M. F. Zuretti, "In the search for new anticancer drugs. 13. Phosphonic and phosphinic analogues of ornithine," Journal of Medicinal Chemistry, vol. 28, no. 9, pp. 1350-1354, 1985.

[25] M. C. Linder, Biochemistry of Copper, Plenum Press, New York, NY, USA, 1991.

[26] M. DiDonato and B. Sarkar, "Copper transport and its alterations in Menkes and Wilson diseases," Biochimica et Biophysica Acta, vol. 1360, no. 1, pp. 3-16, 1997.

[27] B. Sarkar, "Treatment of wilson and menkes diseases," Chemical Reviews, vol. 99, no. 9, pp. 2535-2544, 1999.

[28] M. M. L. Fiallo and A. Garnier-Suillerot, "Metal anthracycline complexes as a new class of anthracycline derivatives," Inorganica Chimica Acta, vol. 137, no. 1-2, pp. 119-121, 1987. 
[29] R. H. Barry, H. Rubin, J. B. Johnson, and J. H. Lazarus, "Theophylline magnesium salicylate a new xanthine compound," Journal of Pharmaceutical Sciences, vol. 70, no. 2, pp. 204-207, 1981.

[30] E. Hać and I. Gagało, "Antipyretic activity of copper salicylate," Polish Journal of Pharmacology and Pharmacy, vol. 39, no. 3, pp. 219-227, 1987.

[31] W. Szczepanik, J. Ciesiołka, J. Wrzesiński, J. Skała, and M. Jeżowska-Bojczuk, "Interaction of aminoglycosides and their copper(II) complexes with nucleic acids: implication to the toxicity of these drugs," Dalton Transactions, no. 8, pp. 14881494, 2003.

[32] M. Jeżowska-Bojczuk, W. Szczepanik, W. Lesniak, J. Ciesiolka, J. Wrzesinski, and W. Bal, "DNA and RNA damage by $\mathrm{Cu}(\mathrm{II})$ amikacin complex," European Journal of Biochemistry, vol. 269, no. 22, pp. 5547-5556, 2002.

[33] B. Halliwell and J. M. C. Gutteridge, "Role of free radicals and catalytic metal ions in human disease: an overview," Methods in Enzymology, vol. 186, pp. 1-85, 1990.

[34] J. M. C. Gutteridge, "Copper-phenanthroline-induced sitespecific oxygen-radical damage to DNA. Detection of loosely bound trace copper in biological fluids," Biochemical Journal, vol. 218, no. 3, pp. 983-985, 1984.

[35] T. D. Rae, P. J. Schmidt, R. A. Pufahl, V. C. Culotta, and T. V. O'Halloran, "Undetectable intracellular free copper: the requirement of a copper chaperone for superoxide dismutase," Science, vol. 284, no. 5415, pp. 805-808, 1999.

[36] C. Leeuwenburgh, J. E. Rasmussen, F. F. Hsu, D. M. Mueller, S. Pennathur, and J. W. Heinecke, "Mass spectrometric quantification of markers for protein oxidation by tyrosyl radical, copper, and hydroxyl radical in low density lipoprotein isolated from human atherosclerotic plaques," Journal of Biological Chemistry, vol. 272, no. 6, pp. 3520-3526, 1997.

[37] S. Fu, M. J. Davies, R. Stocker, and R. T. Dean, "Evidence for roles of radicals in protein oxidation in advanced human atherosclerotic plaque," Biochemical Journal, vol. 333, no. 3, pp. 519-525, 1998.

[38] M. B. Yim, P. B. Chock, and E. R. Stadtman, "Enzyme function of copper, zinc superoxide dismutase as a free radical generator," Journal of Biological Chemistry, vol. 268, no. 6, pp. 40994105, 1993.

[39] T. Theophanides and J. Anastassopoulou, "Copper and carcinogenesis," Critical Reviews in Oncology/Hematology, vol. 42, no. 1, pp. 57-64, 2002.

[40] D. Bar-Or, L. T. Rael, E. P. Lau, et al., "An analog of the human albumin N-terminus (Asp-Ala-His-Lys) prevents formation of copper-induced reactive oxygen species," Biochemical and Biophysical Research Communications, vol. 284, no. 3, pp. 856-862, 2001.

[41] S. E. Bryan, D. L. Vizard, D. A. Beary, R. A. LaBiche, and K. J. Hardy, "Partitioning of zinc and copper within subnuclear nucleoprotein particles," Nucleic Acids Research, vol. 9, no. 21, pp. 5811-5823, 1981.

[42] M. Cappannelli, E. Gaggelli, M. Jeżowska-Bojczuk, et al., " ${ }^{11} \mathrm{H}$ and ${ }^{13} \mathrm{C}$ NMR study of the complex formed by copper(II) with the nucleoside antibiotic sinefungin," Journal of Inorganic Biochemistry, vol. 101, no. 7, pp. 1005-1012, 2007.

[43] A. Mucha, M. Cappanelli, W. Szczepanik, P. Kaczmarek, J. Skała, and M. Jeżowska-Bojczuk, "Influence of the physiologically widespread substances on the oxidative activity of copper(II) complexes with sinefungin, a nucleoside antibiotic," Journal of Inorganic Biochemistry, vol. 100, no. 2, pp. 178-185, 2006.
[44] H. Sigel and R. Griesser, "Nucleoside 5' -triphosphates: selfassociation, acid-base, and metal ion-binding properties in solution," Chemical Society Reviews, vol. 34, no. 10, pp. 875-900, 2005.

[45] R. Tribolet and H. Sigel, "Self-association and protonation of adenosine $5^{\prime}$-monophosphate in comparison with its $2^{\prime}$ - and $3^{\prime}$-analogues and tubercidin $5^{\prime}$-monophosphate (7-deazaAMP)," European Journal of Biochemistry, vol. 163, no. 2, pp. 353-363, 1987.

[46] H. Sigel, "Self-association of nucleotides. Effects of protonation and metal ion coordination," Biological Trace Element Research, vol. 21, pp. 49-59, 1989.

[47] C. Conato, A. Contino, G. Maccarrone, A. Magri, M. Remelli, and G. Tabbi, "Copper(II) complexes with L-lysine and Lornithine: is the side-chain involved in the coordination? A thermodynamic and spectroscopic study," Thermochimica Acta, vol. 362, no. 1-2, pp. 13-23, 2000.

[48] G. Brookes and L. Pettit, "Stability constants for complex formation between cobalt (II), nickel (II), copper (II) and 2, 3diaminopropionic acid, 2, 4-diaminobutyric acid, ornithine, lysine, and arginine," Journal of the Chemical Society, Dalton Transactions, vol. 11, pp. 42-46, 1976.

[49] S. S. Massoud and H. Sigel, "Evaluation of the metalion-coordinating differences between the $2^{\prime}-, 3^{\prime}$ - and $5^{\prime}$ monophosphates of adenosine," European Journal of Biochemistry, vol. 179, no. 2, pp. 451-458, 1989.

[50] E. M. Bianchi, S. A. A. Sajadi, B. Song, and H. Sigel, "Stabilities and isomeric equilibria in aqueous solution of monomeric metal ion complexes of adenosine $5^{\prime}$-diphosphate $\left(\mathrm{ADP}^{3-}\right)$ in comparison with those of adenosine $5^{\prime}$-monophosphate $\left(\mathrm{AMP}^{2-}\right)$," Chemistry - A European Journal, vol. 9, no. 4, pp. 881-892, 2003.

[51] C. F. Naumann, B. Prijs, and H. Sigel, "Adenosine and inosine 5' triphosphates: protonation, metal ion coordination, and charge transfer interaction between two ligands within ternary complexes," European Journal of Biochemistry, vol. 41, no. 2, pp. 209-216, 1974.

[52] P. Kaczmarek, M. Jeżowska-Bojczuk, W. Bal, and K. S. Kasprzak, "Determination of the stability constants and oxidation susceptibility of nickel(II) complexes with $2^{\prime}$ deoxyguanosine $5^{\prime}$-triphosphate and L-histidine," Journal of Inorganic Biochemistry, vol. 99, no. 3, pp. 737-746, 2005.

[53] O. V. Shishkin, G. V. Palamarchuk, L. Gorb, and J. Leszczynski, "Intramolecular hydrogen bonds in canonical 2deoxyribonucleotides: an atoms in molecules study," Journal of Physical Chemistry B, vol. 110, no. 9, pp. 4413-4422, 2006.

[54] B. Knobloch and H. Sigel, "A quantitative appraisal of the ambivalent metal ion binding properties of cytidine in aqueous solution and an estimation of the anti-syn energy barrier of cytidine derivatives," Journal of Biological Inorganic Chemistry, vol. 9, no. 3, pp. 365-373, 2004.

[55] H. Sigel, R. Tribolet, R. Malini-Balakrishnan, and R. Bruce Martin, "Comparison of the stabilities of monomeric metal ion complexes formed with adenosine $5^{\prime}$-triphosphate (ATP) and pyrimidine-nucleoside $5^{\prime}$-triphosphates (CTP, UTP, TTP) and evaluation of the isomeric equilibria in the complexes of ATP and CTP," Inorganic Chemistry, vol. 26, no. 13, pp. 21492157, 1987.

[56] P. W. Schneider, H. Brintzinger, and H. Erlenmeyer, "Zur struktur der ATP.-komplexe zweiwertiger kationen IV. koordinative besetzung des adeninrings," Helvetica Chimica Acta, vol. 47 , no. 4, pp. 992-1002, 1964. 
[57] H. Irving, M. G. Miles, and L. D. Pettit, "A study of some problems in determining the stoicheiometric proton dissociation constants of complexes by potentiometric tetrations using a glass electrode," Analytic Chimica Acta, vol. 38, pp. 475-488, 1967.

[58] P. Gans, A. Sabatini, and A. Vacca, "SUPERQUAD: an improved general program for computation of formation constants from potentiometric data," Journal of the Chemical Society, Dalton Transactions, vol. 1985, pp. 1195-1200, 1985.

[59] M. J. Frisch, G. W. Trucks, H. B. Schlegel, et al., "Gaussian 03, Rev. B.04," Gaussian, Inc., Pittsburgh, Pa, USA, 2003.

[60] A. D. Becke, "Density-functional thermochemistry. III. The role of exact exchange," Journal of Chemical Physics, vol. 98, no. 7, pp. 5648-5652, 1993.

[61] P. J. Stephens, F. J. Devlin, C. F. Chabalowski, and M. J. Frisch, "Ab Initio calculation of vibrational absorption and circular dichroism spectra using density functional force fields," Journal of Physical Chemistry, vol. 98, no. 45, pp. 11623-11627, 1994.

[62] C. Lee, W. Yang, and R. G. Parr, "Development of the ColleSalvetti correlation-energy formula into a functional of the electron density," Physical Review B, vol. 37, no. 2, pp. 785789, 1988.

[63] M. Cossi, V. Barone, R. Cammi, and J. Tomasi, "Ab initio study of solvated molecules: a new implementation of the polarizable continuum model," Chemical Physics Letters, vol. 255, no. 4-6, pp. 327-335, 1996.

[64] G. Schaftenaar and J. H. Noordik, "Molden: a pre- and postprocessing program for molecular and electronic structures," Journal of Computer-Aided Molecular Design, vol. 14, no. 2, pp. 123-134, 2000.

[65] L. Laksonen, "gOpenMol program for the display and analysis of molecular structure," version 2.20, Center for Scientific Computer, Espoo, Finland, http://www.cse.fi/gopenmol/. 


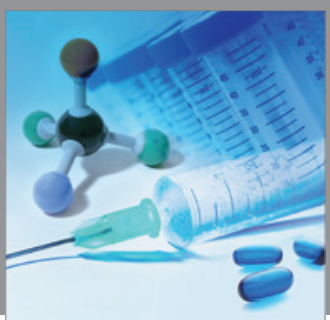

International Journal of

Medicinal Chemistry

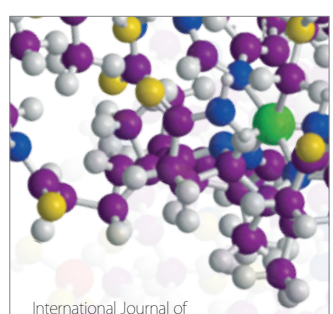

Carbohydrate Chemistry

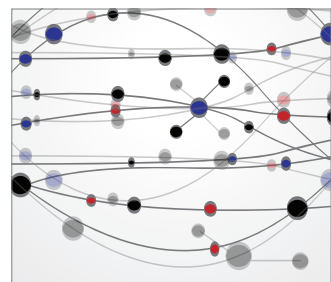

The Scientific World Journal
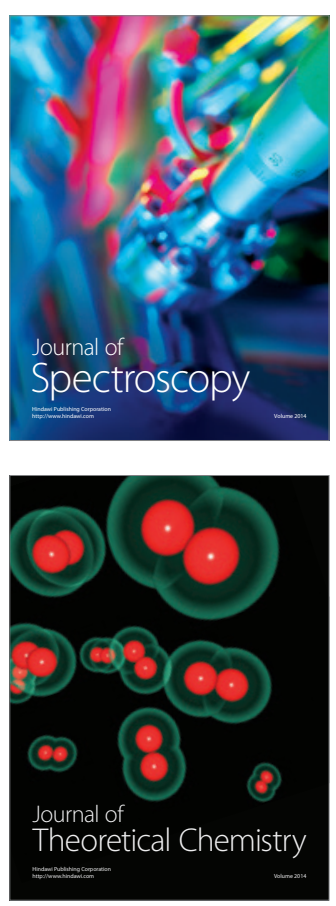
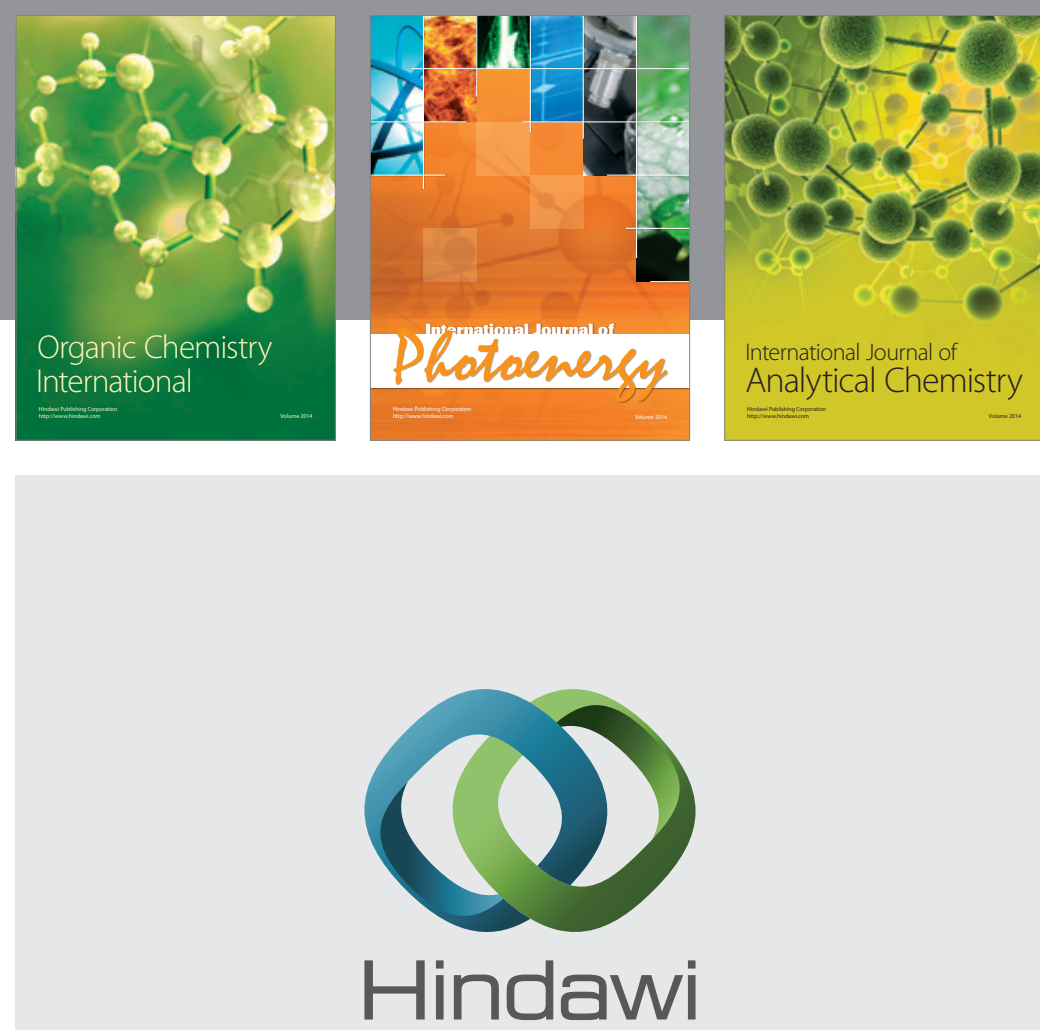

Submit your manuscripts at

http://www.hindawi.com
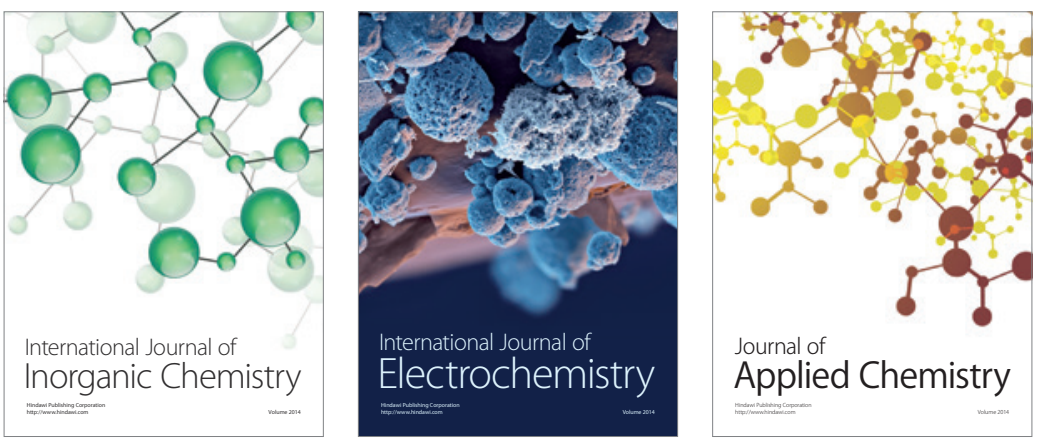

Journal of

Applied Chemistry
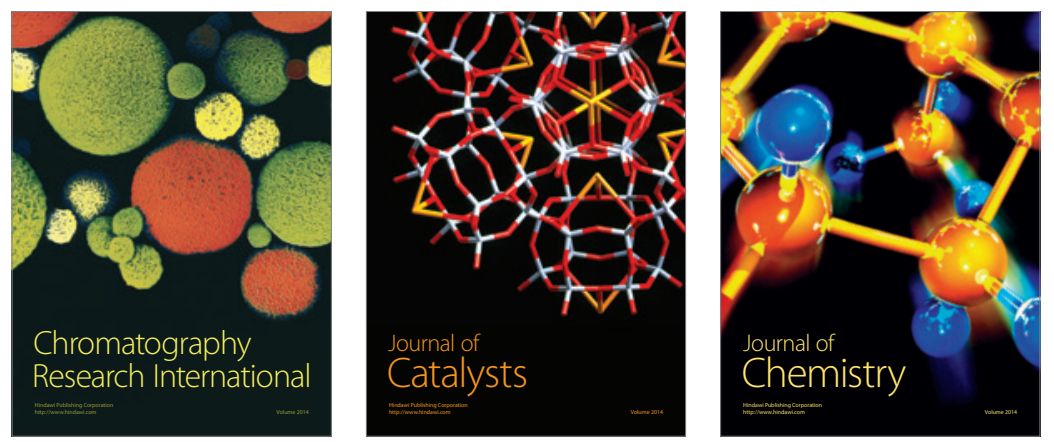
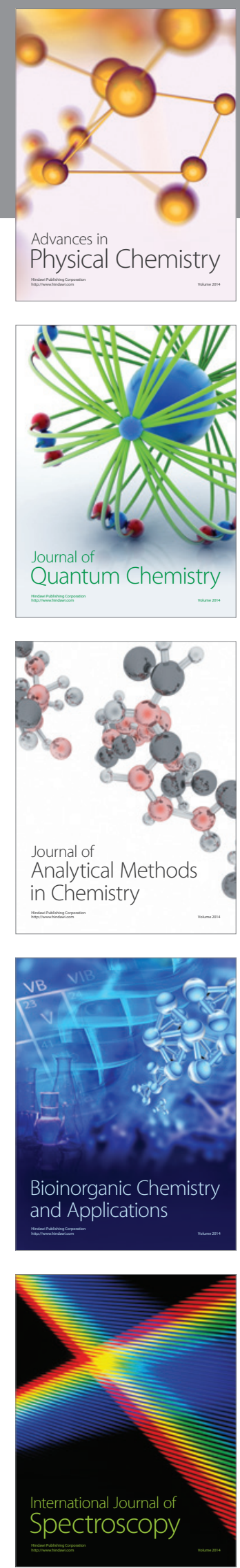